\title{
Analisis Meta Regresi untuk Menjelaskan Heterogenitas Hasil Penelitian pada Kejadian Demam Berdarah Dengue
}

\author{
Shindy*, Muhammad Kasim Aidid, \& Muhammad Nusrang \\ Program Studi Statistika, Fakultas Matematika dan Ilmu Pengetahuan Alam, Universitas Negeri Makassar, Indonesia
}

Keywords: Effect size, Heterogeneity, Meta Regression Analysis, Dengue Hemorrhagic Fever.

\begin{abstract}
:
Meta regression analysis is an analysis that can summarize the results of research with the same topic so that a conclusion is obtained in the form of effect size and can explain the heterogeneity of the results of several studies. In this study using data from the previous Dengue Hemorrhagic Fever incident study which linked the factors of habit of draining habits of water shelters (TPA). Based on the results of the analysis, there was heterogeneity between studies. For the landfill drainage factor, the estimated parameter combined effect size random effect model is 3.60 and the proportion of heterogeneity is $54.08 \%$. The results of the metaregression for habitual factors of landfill drainage factors, the influence of TPA drainage habits can explain heterogeneity between effect sizes.
\end{abstract}

\section{Pendahuluan}

Demam Berdarah Dengue (DBD) masih menjadi salah satu masalah utama dalam bidang kesehatan di Indonesia. Seiring dengan meningkatnya jumlah mobilitas dan kepadatan penduduk, jumlah penderita DBD dan daerah penyebarannya semakin bertambah. Sejak awal Januari 2019, laporan kasus DBD di Indonesia yang terdaftar di Kementerian Kesehatan (Kemenkes) terus bertambah. Berdasarkan data sementara yang dihimpun oleh Kemenkes dari awal Januari hingga akhir Januari 2019, jumlah penderita DBD yang dilaporkan mencapai 13.683 orang di seluruh Indonesia (Syafii, 2019)

Sudah banyak penelitian tentang penyakit DBD yang telah dilakukan. Faktor yang sering dikaitkan dengan DBD kebiasaan menguras tempat penampungan air (TPA). Beberapa penelitian sebelumnya yang dilakukan di beberapa daerah menyatakan bahwa menguras TPA berpengaruh terhadap kejadian DBD, diantaranya yaitu penelitian yang dilakukan oleh Yunita dkk (2012), Ayun dan Pawenang (2017), serta Mahardika (2009). Sedangkan menurut penelitian Rahman (2012) mengatakan kebiasaan menguras TPA tidak berpengaruh terhadap kejadian DBD. Perbedaan pendapat yang disimpulkan dalam penelitian-penelitian sebelumnya terkait kebiasaan menguras TPA menjadi alasan penelitian ini dilakukan. Hasil yang bertolak belakang menyebabkan penelitian-penelitian sebelumnya perlu dikaji ulang.

Salah satu metode yang dapat digunakan untuk menggabungkan dua atau lebih penelitian adalah meta analisis. Meta analisis merupakan suatu teknik statistika yang mengkombinasikan beberapa hasil penelitian sehingga didapatkan paduan data secara kuantitatif. Melalui meta analisis, dapat diperoleh perbedaan hasil antar peubah dan memberikan estimasi efek gabungan serta heterogenitas dari seluruh peubah. Pendekatan yang dapat digunakan untuk menjelaskan heterogenitas dari hasil penelitian meta analisis adalah pendekatan meta regresi. Meta regresi dapat memberikan bukti

\footnotetext{
* Corresponding author.

E-mail address: aditio.putra@gmail.com
} 
yang kuantitatif sehingga dapat menjelaskan heterogenitas dalam penelitian-penelitian sebelumnya. Dalam penelitian ini menggunakan metode meta regresi untuk menjelaskan heterogenitas hasil dari beberapa penelitian sebelumnya dengan melihat faktor kebiasaan menguras tempat penampungan air yang mempengaruhi kejadian Demam Berdarah Dengue di beberapa daerah di Indonesia.

\section{Tinjauan Pustaka}

\subsection{Effect size}

Effect size merupakan ukuran mengenai signifikansi praktis hasil penelitian yang berupa ukuran besarnya korelasi atau perbedaan, atau efek dari suatu peubah pada peubah lain. Melalui nilai effect size, dapat menggambarkan secara umum kekuatan korelasi diantara dua peubah. Selain itu, informasi mengenai effect size ini dapat digunakan juga untuk membandingkan efek suatu peubah dari penelitian-penelitian yang menggunakan skala pengukuran berbeda (Santoso, 2010).

Effect size terbagi atas 3 jenis yakni risk ratio, Odds Ratio dan risk difference. Perhitungan effect size dari hasil nilai Odds Ratio menggunakan data biner berordo $(2 \times 2)$ adalah sebagai berikut (Borenstein dkk, 2009) .

Tabel 1 Tabel data biner berordo $(2 \times 2)$

\begin{tabular}{lccc}
\hline & Event & Non-Event & Total \\
\hline Treated & $\mathrm{A}$ & $\mathrm{B}$ & $\mathrm{n}_{1}$ \\
Control & $\mathrm{C}$ & $\mathrm{D}$ & $\mathrm{n}_{2}$ \\
\hline
\end{tabular}

Bentuk $\log$ Odds Ratio :

$$
\ln (O R)=\ln \left(\frac{A D}{B C}\right)
$$

\subsection{Meta Analisis}

Meta analisis merupakan suatu teknik statistika untuk menggabungkan hasil 2 atau lebih penelitian sejenis sehingga diperoleh paduan data secara kuantitatif (Anwar, 2005). Meta analisis dapat digunakan untuk mengatasi keragaman hasil dari beberapa penelitian. Secara singkat meta analisis melibatkan proses identifikasi, pengumpulan, meninjau kembali, mengkodekan serta menginterpretasikan berbagai riset penelitian. Tujuan utama dari meta analisis adalah merangkum hasil penelitian-penelitian dengan topik yang sama untuk memperoleh sebuah kesimpulan berupa effect size. Pemodelan dalam meta analisis dibedakan atas dua, yaitu model fix effect dan model random effect.

Model fix effect mengasumsikan bahwa penelitian yang dimodelkan adalah homogen, yang artinya tidak terdapat perbedaan antar penelitian. Model fix effect meta analisis adalah sebagai berikut (Borenstein dkk, 2009).

$$
\begin{aligned}
y_{i} & =\theta+\varepsilon_{i} \\
\text { dimana, } &
\end{aligned}
$$

$$
\begin{aligned}
& y_{i}=\text { nilai } \text { effect size }(\ln \text { Odds Ratio }) \text { pengamatan ke- } i \\
& \theta=\text { parameter umum effect size gabungan } \\
& \varepsilon_{i}=\text { error pengamatan ke- } i, \varepsilon_{i} \sim N\left(0, \sigma^{2}\right)
\end{aligned}
$$

Untuk mengestimasi parameter $\theta$ dapat menggunakan metode Weighted Least Square (WLS) :

$$
\text { dengan }
$$$$
\theta=\frac{\sum_{i=1}^{k} w_{i} y_{i}}{\sum_{i=1}^{k} w_{i}}
$$

$$
w_{i}=\frac{1}{\sigma_{i}^{2}}
$$

Untuk melihat heterogenitas antar pengamatan $(Q)$, dapat menggunakan persamaan berikut (Borenstein dkk, 2009) . 


$$
Q=\sum_{i=1}^{k} w_{i} y_{i}^{2}-\frac{\left(\sum_{i=1}^{k} w_{i} y_{i}\right)^{2}}{\sum_{i=1}^{k} w_{i}}
$$

Jika nilai $Q>\chi_{(k-1 ; \alpha)}^{2}$, maka $\mathrm{H}_{0}$ ditolak, artinya varians effect size gabungan heterogen atau effect size gabungan tidak sama pada semua penelitian.

Jika terjadi heterogenitas pada model fix effect, terutama jika hasil heterogenitas berpengaruh signifikan, maka pemodelan yang lebih tepat digunakan adalah random effect model yaitu :

dengan

$$
y_{i}=\theta+v_{i}+\varepsilon_{i}
$$

$v_{i}=$ variasi nyata effect size, $v_{i} \sim N\left(0, \sigma_{\tau}^{2}\right)$

Bobot yang diberikan untuk setiap penelitian random effect diberikan sebagai berikut.

$$
w_{i}^{*}=\frac{1}{V_{y_{i}}^{*}}=\frac{1}{\sigma^{2}+\sigma_{\tau}^{2}}
$$

Estimasi gabungan populasi effect size adalah :

$$
\theta^{*}=\frac{\sum_{i=1}^{k} w_{i}^{*} y_{i}}{\sum_{i=1}^{k} w_{i}^{*}}
$$

\subsection{Meta Regresi}

Meta regresi merupakan perluasan dari meta analisis, dimana meta regresi dapat menyelidiki sejauh mana heterogenitas antara hasil beberapa penelitian dapat dikaitkan dengan satu atau lebih dari karakakteristik penelitian tersebut (Thompson dan Higgins, 2002).

Meta regresi merupakan metode yang dapat digunakan untuk menjelaskan adanya heterogenitas dengan menghubungkan antara effect size dari satu atau lebih karakteristik umum penelitian untuk memahami perbedaan antar penelitian. Meta regresi pada dasarnya merupakan kasus sederhana dari model gabungan (mixed effect model) yakni menggunakan model fix effect sebagai iterasi awal dan dilanjutkan dengan model random effect.

Pada model fix effect menggunakan kovariat dan mengasumsikan bahwa varians antar penelitian bernilai 0. Model fix effect meta regresi diberikan pada persamaan berikut (Card, 2012) : dimana:

$$
y_{i}=\beta_{0}+\beta_{1} x_{i 1}+\beta_{2} x_{i 2}+\cdots+\beta_{m} x_{i m}+\varepsilon_{i}
$$

$y_{i}=$ nilai effect size pengamatan pada penelitian ke- $i$

$\beta_{0}=$ nilai konstanta

$\beta_{m}=$ nilai koefesien regresi $(\mathrm{m}=$ jumlah kovariat $)$

$x_{i m}=$ nilai kovariat yang diikutkan dalam model

$\varepsilon_{i}=$ error, $\varepsilon_{i} \sim N\left(0, \sigma_{i}^{2}\right)$

Untuk mengestimasi parameter $\beta$ dapat menggunakan metode WLS yaitu:

$$
\hat{\beta}=\left(X^{T} V^{-1} X\right)^{-1} X^{T} V^{-1} y
$$

Pengujian parameter menggunakan lebih dari satu kovariat dilakukan menggunakan uji serentak dan uji parsial. Uji serentak dilakukan untuk mengetahui hubungan dari seluruh kovariat secara simultan berpengaruh terhadap effect size.

Statistik uji yang digunakan:

$$
\begin{aligned}
Q_{\text {model }} & =Q_{\text {total }}-Q_{\text {error }} \\
& =\sum_{i=1}^{k} w_{i}\left(\hat{y}_{i}-\bar{y}_{w}\right)^{2}
\end{aligned}
$$

Jika $Q_{\text {model }}>\chi_{(m-1 ; \alpha)}^{2}$, maka $\mathrm{H}_{0}$ ditolak, artinya terdapat kovariat yang berpengaruh terhadap effect size.

Sedangkan statitistik uji untuk menguji homogenitas adalah:

$$
Q_{\text {error }}=\sum_{i=1}^{k} w_{i}\left(y_{i}-\hat{y}_{i}\right)^{2}
$$


Jika $Q_{\text {error }}>\chi_{(k-m ; \alpha)}^{2}$, maka $\mathrm{H}_{0}$ ditolak, artinya terdapat sisa heterogenitas yang tidak dijelaskan dalam model yang berarti memungkinkan terdapat kovariat lain yang berpengaruh terhadap effect size tetapi tidak diikutkan dalam model.

Setelah itu, dilanjutkan dengan uji parsial pada masing-masing parameter koefisien regresi dengan menggunakan :

$$
Z_{\text {hitung }}=\frac{\widehat{\beta}_{i}}{\operatorname{SE}\left(\widehat{\beta}_{i}\right)}
$$

Jika nilai $\left|Z_{\text {hitung }}\right|>\mathrm{Z}_{\alpha / 2}$, maka $\mathrm{H}_{0}$ ditolak.

Model random effect meta regresi adalah model yang menggunakan satu atau lebih kovariat dan bertujuan untuk mengidentifikasi peubah apa yang berpengaruh terhadap effect size. Model random effect meta regresi merupakan kasus sederhana dari general linear mixed model dengan varians sampling diketahui dari tiap-tiap penelitian, sehingga estimasi parameter dan statistik inferensia dapat diperoleh dari efek model gabungan. Model meta regresi dengan lebih dari satu kovariat dapat ditulis sebagai berikut (Card, 2012) :

$$
y_{i}=\beta_{0}+\beta_{1} x_{i 1}+\beta_{2} x_{i 2}+\cdots+\beta_{m} x_{i m}+v_{i}+\varepsilon_{i}
$$

dengan $v_{i} \sim N\left(0, \sigma_{\tau}^{2}\right)$ dan $\varepsilon_{i} \sim N\left(0, \sigma_{i}^{2}\right)$.

Pengujian estimasi parameter model meta regresi menggunakan uji serentak dan uji parsial. Pengujian serentak dan parsial sama seperti pada pengujian fix effect meta regresi tetapi menggunakan bobot $w_{i}^{*}=1 /\left(\sigma_{i}^{2}+\sigma_{\tau}^{2}\right)$.

Setelah melakukan pengujian serentak dan parsial, selanjutnya menentukan seberapa besar proporsi varians yang dapat dijelaskan oleh kovariat dengan menggunakan perhitungan koefisien determinasi berikut :

$$
\begin{aligned}
& R^{2}=\left(1-\frac{\sigma_{\text {tunexplained }}^{2}}{\sigma_{\text {t total }}^{2}}\right) \times 100 \% \\
& \sigma_{\tau \text { unexplained }}^{2} \quad=\text { varians antar penelitian dengan melibatkan kovariat } \\
& \sigma_{\tau}^{2} \text { total } \quad=\text { varians antar penelitian tanpa melibatkan kovariat }
\end{aligned}
$$

\subsection{Demam Berdarah Dengue}

Penyakit Demam Berdarah Dengue (DBD) adalah penyakit yang disebabkan oleh virus Dengue yang ditularkan melalui gigitan nyamuk dari genus Aedes, terutama Aedes aegypti atau Aedes albopictus (Kemenkes RI, 2018). Saat ini, penderita DBD di Indonesia semakin bertambah. Hal ini dilihat dari tingginya kasus DBD mulai awal tahun 2019. Perilaku masyarakat terhadap sekitarnya dapat menjadi faktor penyebab penyakit DBD. Faktor yang sering dikaitkan dengan penyakit DBD adalah kebiasaan menguras tempat penampungan air (TPA). TPA yang tidak ada tutupnya dan terlindung dari sinar matahari, merupakan tempat yang disukai oleh nyamuk. Oleh sebab itu sebaiknya perlu dilakukan tindakan pencegahan yakni dengan menguras TPA sehingga tidak memberi kesempatan telur untuk berkembang biak menjadi nyamuk dewasa. (Dinkes RI, 2010).

\section{Metode Penelitian}

\subsection{Jenis Penelitian dan Sumber Data}

Pada penelitian ini menggunakan penelitian kuantitatif dimana peneliti mengambil data dari dari penelitian-penelitian (jurnal, skripsi, dan tesis) yang telah dilakukan di beberapa daerah Indonesia yang mengaitkan kejadian DBD dengan faktor kebiasaan menguras tempat penampungan air.

\subsection{Definisi Operasional Peubah}

Adapun definisi dari peubah-peubah yang digunakan dalam penelitian ini adalah

a. $\quad$ Effect size (Y)

Nilai effect size diperoleh dari nilai ln Odds Ratio dari masing-masing penelitian sebelumnya. 
b. Pengaruh kebiasaan menguras TPA (X2)

Pengaruh kebiasaan menguras TPA dapat dilihat dari seberapa sering responden dalam menguras TPA, dimana dikatetegorikan jarang apabila menguras TPA kurang dari sekali seminggu, dan dikategorikan sering apabila menguras TPA lebih dari atau sama dengan sekali seminggu.

c. Lokasi Penelitian (X3)

Lokasi penelitian dibedakan menjadi dua, yaitu dataran rendah dan dataran tinggi. Lokasi dikategorikan rendah apabila berada kurang dari 200 meter dari permukaan laut, sedangkan dikategorikan tinggi apabila berada lebih dari sama dengan 200 meter dari permukaan laut (Sungkawa,2010).

d. Desain Penelitian (X4)

Desain penelitian dalam penelitian ini dikategorikan menjadi dua yaitu desain case control dan desain case sectional

\subsection{Langkah Analisis}

Langkah-langkah analisis meta regresi dalam penelitian ini adalah sebagai berikut:

a. Mengumpulkan data dari hasil penelitian terkait kejadian DBD.

b. Mengidentifikasi data faktor risiko DBD

c. Meringkas data DBD yang telah dikumpulkan sesuai dengan kriteria data yang diperlukan.

d. Menghitung effect size (ln Odds Ratio) dan varians ln Odds Ratio setiap data penelitian.

e. Melakukan analisis fix effect meta analisis

f. Melakukan analisis random effect meta analisis

g. Melakukan analisis fix effect meta regresi

h. Melakukan analisis random effect meta regresi

i. Menarik kesimpulan

\section{Hasil dan Pembahasan}

\subsection{Penyeleksian Data Hasil Penelitian}

Jumlah penelitian sebelumnya terkait kejadian Demam Berdarah Dengue (DBD) yang terkumpul adalah sebanyak 84 penelitian. Kemudian dilakukan proses seleksi penelitian dengan kriteria sebagai berikut :
a. Terdapat faktor kebiasaan menguras tempat penampungan air (TPA)
b. Melaporkan hasil dalam bentuk Odds Ratio
c. Data penelitian jelas
d. Menggunakan desain penelitian case control atau cross sectional
e. Penelitian dilakukan di daerah Indonesia

Setelah proses seleksi dilakukan terdapat 12 penelitian untuk faktor kebiasaan menguras TPA yang digunakan untuk penelitian ini.

\subsection{Effect size}

Tahap pertama sebelum pemodelan meta analisis adalah dengan menentukan terlebih dahulu nilai effect size dari masing-masing penelitian. Nilai effect size $\left(y_{i}\right)$ diperoleh dari nilai Odds Ratio yang ditransformasi dalam bentuk $\mathrm{ln}$ Odds Ratio dan nilai varians effect size $\left(v_{i}\right)$ diperoleh dari $\operatorname{Var}(\operatorname{Ln}(\mathrm{OR}))$

Tabel 2 Nilai effect size

\begin{tabular}{clcccccccc}
\hline No & Penulis & Tahun & A & B & C & D & OR & $\boldsymbol{y}_{\boldsymbol{i}}$ & $\boldsymbol{v}_{\boldsymbol{i}}$ \\
\hline 1 & Azhari & 2004 & 41 & 13 & 14 & 40 & 9,0110 & 2,1984 & 0,1977 \\
2 & Wahyu & 2009 & 26 & 13 & 14 & 27 & 3,8571 & 1,3499 & 0,2239 \\
3 & Herlina & 2011 & 126 & 78 & 74 & 122 & 2,6632 & 0,9795 & 0,0425
\end{tabular}




\begin{tabular}{clcccccccc}
\hline No & Penulis & Tahun & A & B & C & D & OR & $\boldsymbol{y}_{\boldsymbol{i}}$ & $\boldsymbol{v}_{\boldsymbol{i}}$ \\
\hline 4 & Jasrida & 2012 & 29 & 59 & 27 & 109 & 1,9843 & 0,6853 & 0,0976 \\
5 & Deni & 2012 & 4 & 3 & 24 & 25 & 1,3889 & 0,3285 & 0,6650 \\
6 & Mentary & 2013 & 25 & 10 & 19 & 26 & 3,4211 & 1,2299 & 0,2311 \\
7 & Beny dan Febri & 2013 & 18 & 46 & 2 & 101 & 19,7609 & 2,9837 & 0,5872 \\
8 & Maurien dkk & 2015 & 25 & 10 & 11 & 26 & 5,9091 & 1,7765 & 0,2694 \\
9 & Vandi dkk & 2015 & 14 & 13 & 24 & 25 & 1,1218 & 0,1149 & 0,2300 \\
10 & Luluk dan Eram & 2017 & 16 & 4 & 10 & 22 & 8,8000 & 2,1748 & 0,4580 \\
11 & Bibah dkk & 2017 & 25 & 10 & 32 & 47 & 3,6719 & 1,3007 & 0,1925 \\
12 & Eudia dkk & 2017 & 15 & 6 & 22 & 31 & 3,5227 & 1,2592 & 0,3110 \\
\hline
\end{tabular}

Keterangan :
$\mathrm{A}=$ Kelompok individu terinfeksi DBD yang jarang menguras TPA
$\mathrm{B}=$ Kelompok individu tidak terinfeksi DBD yang jarang menguras TPA
$\mathrm{C}=$ Kelompok individu terinfeksi DBD yang sering menguras TPA
$\mathrm{D}=$ Kelompok individu tidak terinfeksi DBD sering menguras TPA

Berdasarkan Tabel 2 menunjukkan bahwa terdapat semua penelitian menghasilkan nilai ln Odds Ratio yang bernilai positif, artinya dari seluruh penelitian tersebut, kecenderungan untuk terinfeksi DBD bagi individu yang jarang menguras TPA lebih besar dibandingkan individu yang sering menguras TPA.

\subsection{Fix effect Model Meta Analisis}

Pada tahapan ini, dapat dilihat hasil uji homogenitas (Q) terhadap faktor kebiasaan menguras TPA.

Tabel 3 Hasil nilai Q

\begin{tabular}{cl}
\hline $\mathbf{Q}$ & df \\
\hline 23,9562 & 11 \\
\hline
\end{tabular}

Pada Tabel 3 merupakan hasil nilai Q yang diperoleh dari Persamaan (2.5). Hasil pengujian homogenitas yang dilihat dari nilai Q sebesar 23,9562 yang lebih besar dari $\chi_{(11 ; 0.05)}^{2}=19,7$ dengan taraf signifikasi $5 \%$, sehingga tolak $\mathrm{H}_{0}$ yang berarti varians effect size heterogen. Karena terjadi heterogenitas antar penelitian, maka model random effect lebih tepat digunakan.

\subsection{Random effect Model Meta Analisis}

Pada Tabel 4 dapat dilihat hasil analisis random effect meta analisis untuk faktor kebiasan menguras TPA.

Tabel 4 Hasil analisis random effect meta analisis

\begin{tabular}{ccccc}
\hline Estimasi $\boldsymbol{\theta}$ & Standar Error & Z hitung & Interval Kepercayaan (95\%) & Exp ( $\boldsymbol{\theta})$ \\
\hline 1,2815 & 0,1961 & 6,5355 & 0,$8972 ; 1,6658$ & 3,60 \\
\hline
\end{tabular}

Dari hasil output analisis meta model random effect diatas menunjukkan nilai $\left|Z_{\text {hitung }}\right|=6,5355$ lebih besar dari $Z_{(0.05 / 2)}=1,96$, artinya gabungan populasi effect size berpengaruh signifikan terhadap effect size pengamatan. Hasil estimasi gabungan populasi effect size adalah exp $(1,2815)=3,60$ sehingga model random effect meta analisis berdasarkan Persamaan (2.6) adalah :

$$
y=3,60
$$

Nilai effect size gabungan memberikan hasil sebesar 3,60 artinya individu yang jarang menguras TPA cenderung hampir empat kali berpeluang terkena penyakit DBD dibandingkan dengan individu yang sering menguras TPA. 


\subsection{Fix effect Model Meta Regresi}

Dalam meta regresi model fix effect digunakan sebagai iterasi awal dengan mengasumsikan variasi penelitian bernilai nol. Sebelum melakukan pemodelan fix effect, terlebih dahulu melakukan pengujian serentak dan pengujian parsial. Pengujian serentak dilakukan dengan menggunakan uji $Q_{\text {model }}$.

Tabel 5 Pengujian serentak untuk Faktor Kebiasaan Menguras TPA

\begin{tabular}{ccc}
\hline Sumber Variansi & Q & df \\
\hline$Q_{\text {error }}$ & 12,7773 & 8 \\
$Q_{\text {model }}$ & 11,1789 & 3 \\
$Q_{\text {total }}$ & 23,9562 & 11 \\
\hline
\end{tabular}

Berdasarkan hasil uji serentak pada Tabel 5 dengan taraf signifikasi $10 \%$, didapatkan nilai $Q_{\text {model }}$ sebesar 11,1789 yang lebih besar dari $\chi_{(3 ; 0.1)}^{2}=6,25$, artinya paling sedikit terdapat satu kovariat yang berpengaruh terhadap effect size. Selanjutnya dilakukan uji parsial terhadap masing-masing kovariat dengan hasil pada Tabel 6.

Tabel 6 Hasil analisis fix effect meta regresi untuk faktor kebiasaan menguras TPA

\begin{tabular}{lcccc}
\hline & Estimasi & SE & Z hitung & Interval Kepercayaan (90\%) \\
\hline Intercept & 0,1698 & 0,4134 & 0,4108 & $-0,6404 ; 0,9801$ \\
Kebiasaan (tinggi) & 0,9523 & 0,4362 & 2,1833 & 0,$0974 ; 1,8071$ \\
Lokasi (tinggi) & 0,8019 & 0,4347 & 1,8449 & $-0,1084 ; 1,5863$ \\
Desain (cross) & 0,6032 & 0,4303 & 1,4017 & $-0,2402 ; 1,4465$ \\
\hline
\end{tabular}

Berdasarkan hasil uji parsial dari tiga variabel, hanya peubah kebiasaan tinggi $\left(\mathrm{X}_{1(1)}\right)$ dan peubah lokasi tinggi $\left(\mathrm{X}_{2(1)}\right)$ yang berpengaruh terhadap effect size berdasarkan taraf signifikansi $10 \%$, sehingga dilakukan lagi uji serentak untuk kedua peubah tersebut sehingga mendapatkan hasil pada Tabel 7.

Tabel 7 Hasil uji serentak untuk Faktor Kebiasaan Menguras TPA

\begin{tabular}{ccc}
\hline Sumber Variansi & $\mathbf{Q}$ & df \\
\hline$Q_{\text {error }}$ & 14,7421 & 9 \\
$Q_{\text {model }}$ & 9,2142 & 2 \\
$Q_{\text {total }}$ & 23,9563 & 11 \\
\hline
\end{tabular}

Berdasarkan hasil uji serentak pada Tabel 4.6 didapatkan nilai $Q_{\text {model }}$ sebesar 9,2142 yang lebih besar dari $\chi_{(2 ; 0.1)}^{2}=$ 4,6, artinya paling sedikit terdapat satu kovariat yang berpengaruh terhadap effect size. Selanjutnya dilakukan uji parsial terhadap masing-masing kovariat, dengan hasil pada Tabel 8.

Tabel 8 Hasil fix effect meta regresi untuk kovariat kebiasaan dan lokasi

\begin{tabular}{lcccc}
\hline & Estimasi & SE & Z hitung & Interval Kepercayaan (90\%) \\
\hline Intercept & 0,1698 & 0,4134 & 0,4108 & $-0,6404 ; 0,9801$ \\
Kebiasaan (tinggi) & 1,0152 & 0,4338 & 2,3401 & 0,$1649 ; 1,8655$ \\
Lokasi (tinggi) & 0,7389 & 0,4323 & 1,7091 & $-0,1084 ; 1,5863$ \\
\hline
\end{tabular}

Hasil pengujian parsial menunjukkan bahwa nilai $Z$ hitung untuk peubah kebiasaan tinggi $\left(\mathrm{X}_{2(1)}\right)$ sebesar 2,3401 dan peubah lokasi tinggi $\left(\mathrm{X}_{3(1)}\right)$ sebesar 1,7091 lebih besar dibandingkan dengan nilai $Z_{(0.1 / 2)}$ sebesar 1,645 sehingga tolak $\mathrm{H}_{0}$ artinya kedua variabel berpengaruh terhadap nilai effect size. Model fix effect untuk kebiasaan menguras TPA adalah: 


$$
y_{i}=0,1698+1,0152\left(\mathrm{X}_{2(1)}\right)+0,7389\left(\mathrm{X}_{3(1)}\right)
$$

\subsection{Random effect Model Meta Regresi}

Setelah mendapat model fix effect, dilanjutkan dengan pemodelan random effect untuk mendapatkan model dengan melibatkan variasi antar penelitian. Hasil estimasi untuk model random effect meta regresi berdasarkan Persamaan (2.14) adalah:

Tabel 9 Hasil analisis random effect meta regresi untuk faktor kebiasaan menguras TPA

\begin{tabular}{lcccc}
\hline & Estimasi & SE & Z hitung & Interval Kepercayaan (90\%) \\
\hline Intercept & 0,1747 & 0,4463 & 0,3915 & $-0,7000 ; 1,0494$ \\
Kebiasaan (ti & 1,0805 & 0,4748 & 2,2759 & 0,$1500 ; 2,0110$ \\
Lokasi (tinggi) & 0,6746 & 0,4696 & 1,4366 & $-0,2458 ; 1,5950$ \\
\hline
\end{tabular}

Sebelum melakukan pemodelan, dilakukan pengujian serentak dan pengujian parsial seperti pada fix effect model. Hasil pengujian serentak ditunjukkan pada Tabel 10.

Tabel 10 Hasil uji serentak random effect meta regresi untuk kovariat kebiasaan dan lokasi

\begin{tabular}{ccc}
\hline Sumber Variansi & Q & df \\
\hline$Q_{\text {error }}$ & 14,7421 & 9 \\
$Q_{\text {model }}$ & 8,1255 & 2 \\
$Q_{\text {total }}$ & 22,8676 & 11 \\
\hline
\end{tabular}

Berdasarkan hasil uji serentak dengan taraf signifikansi 10\%, menghasilkan nilai Q model sebesar 8,1255 yang lebih besar dari $\chi_{(2 ; 0.1)}^{2}=4,6$ sehingga tolak $\mathrm{H}_{0}$ yang berarti paling sedikit ada satu peubah yang berpengaruh terhadap effect size.

Setelah melakukan uji serentak, dilanjutkan dengan uji parsial yang dapat dilihat dari nilai Z hitung masing-masing peubah. Berdasarkan hasil $\mathrm{Z}$ hitung pada Tabel 4.8 menunjukkan peubah kebiasaan menghasilkan nilai yang lebih besar dari $z_{(0.1 / 2)}=1,645$, sehingga tolak $\mathrm{H}_{0}$ yang artinya peubah kebiasaan berpengaruh signifikan terhadap effect size.

Selanjutnya dapat dihitung koefisien determinasi dipeoleh dari Persamaan (2.44) sebagai berikut :

$$
R^{2}=\left(1-\frac{\sigma_{\text {tunexplained }}^{2}}{\sigma_{\text {t total }}^{2}}\right) \times 100 \%=\left(1-\frac{0.0466}{0.2236}\right) \times 100 \%=79,16 \%
$$

Hasil nilai $R^{2}$ sebesar $79.16 \%$ artinya sebesar $79,16 \%$ dari proporsi varians antar penelitian dapat dijelaskan oleh peubah kebiasaan. Model random effect meta regresi dapat ditulis sebagai berikut:

$$
y_{i}=0,1747+1,0805\left(\mathrm{X}_{2(1)}\right)
$$

Dari model diatas diketahui bahwa setiap pengaruh kebiasaan jarang menguras TPA yang tinggi akan menambahkan kecenderungan untuk terinfeksi DBD sebesar exp $(1,0805)=2,94$ atau 3 kali dibandingkan dengan pengaruh yang rendah.

\section{Kesimpulan}

1) Berdasarkan hasil meta analisis untuk faktor kebiasaan menguras TPA hasil meta analisis menunjukkan bahwa terjadi heterogenitas antar penelitian dengan proporsi varians antar penelitian sebesar 54,08\%. Hasil estimasi parameter gabungan effect size model random effect adalah 3,60 yang artinya individu yang memiliki kebiasaan 
yang jarang menguras TPA cenderung hampir empat kali berpeluang terinfeksi DBD dibandingkan dengan individu yang sering menguras TPA.

2) Berdasarkan hasil meta regresi dengan model random effect untuk faktor kebiasaan menguras TPA, hasil meta regresi dengan model random effect didapatkan hanya peubah kebiasaan yang tinggi yang berpengaruh terhadap heterogenitas antar penelitian. Peubah kebiasaan dapat menjelaskan heterogenitas antar penelitian sebesar $79,16 \%$.

\section{References}

Alifan, A. (2016). Estimasi Model Meta-Regresi Berdasarkan Metode Weighted Least Square (Doctoral dissertation, Universitas Airlangga).

Anwar, R. (2005). Meta Analisis. Pertemuan Fertilitas Endokrinologi Reproduksi bagian Obstetri dan Ginekologi RSHS/FKUP Bandung, (pp. 1-18). Bandung.

Ayun, L. L., \& Pawenang, E. T. (2017). Hubungan antara Faktor Lingkungan Fisik dan Perilaku dengan Kejadian Demam Berdarah Dengue (DBD) Di Wilayah Kerja Puskesmas Sekaran, Kecamatan Gunungpati, Kota Semarang. Public Health Perspective Journal, 97-104.

Card, N. A. (2012). Applied Meta-Analysis for Social Science Research. New York: The Guilford Press.

Borenstein, M., Hedges, L. V., Higgins, J. P., \& Rothstein, H. R. (2009). Introduction to Meta Analysis. UK: TJ International, Padstow, Cornwall.

Dinkes RI. (2010). Pencegahan dan Pemberantasan Demam Berdarah Dengue, Jakarta: Dirjen P2L.

Kemenkes, RI. (2018). Profil Kesehatan Indonesia Tahun 2017. Jakarta: Kementerian Kesehatan Republik Indonesia.

Khalimah, N. H. (2015). Analisis Meta Regresi Untuk Menjelaskan Heterogenitas Hasil Beberapa Penelitian Pada Faktor Ventilasi Dan Pencahayaan Yang Mempengaruhi Tuberkulosis Di Indonesia (Doctoral dissertation, Institut Technology Sepuluh Nopember).

King, W. R \& Jun, H. (2005). Understanding the Role and Methods of Meta-Analysis in IS Research. Communications of the Association for Information Systems, 665-686.

Mahardika, W. (2009). Hubungan Antara Perilaku Kesehatan dengan Kejadian Demam Berdarah Dengue (DBD) di Wilayah Kerja Puskesmas Cepiring Kecamatan Cepiring Kabupaten Kendal Tahun 2009 (Doctoral dissertation, Universitas Negeri Semarang).

Ngafiyah, A. N., \& Widjanarko, B. (2014). Meta-Analityc Structural Equation Modeling (MASEM) Pada FaktorFaktor yang Mempengaruhi Kemiskinan di Pulau Jawa. Prosiding Seminar Nasional Matematika (pp. 5162). Surabaya: Universitas Jember.

Prasiska, D. I. (2014). Analisis Faktor Risiko Berat Badan Lahir pada Kematian Perinatal Menggunakan Meta Analysis. Jurnal Biometrika dan Kependudukan, 28-33.

Rahman, D. A. (2012). Hubungan Kondisi Lingkungan Rumah dan Praktik 3M dengan Kejadian Demam Berdarah Dengue (DBD) di Wilayah Kerja Puskesmas Blora Kabupaten Blora. Unnes Journal of Public Health, 1-7.

Riyandi, G. (2012). Analisis Meta Permintaan Uang di Indonesia. Buletin Ekonomi Moneter dan Perbankan, 39-60.

Tiro, M. A. (2010). Analisis Korelasi dan Regresi. Makassar: Andira Publisher, Makassar.

Santoso, A. (2010). Studi Deskriptif Effect size Penelitian-Penelitian di Fakultas Psikologi Universitas Sanata Dharma. Jurnal Penelitian, 14(1).

Sungkawa, D. (2008). Geografi Regional Indonesia. Bandung : UniversitasPendidikan Indonesia.

Syafii, M. (2019). 13.683 Kasus DBD di Indonesia dalam Sebulan, 133 Orang Meninggal. Jawa Timur: Kompas. (http://www.kompas.com) diakses pada tanggal 3 Februari 2019

Yunita, J., Mitra, \& Susmaneli, H. (2012). Pengaruh Perilaku Masyarakat dan Kondisi Lingkungan Terhadap Kejadian Demam Berdarah Dengue. Jurnal Kesehatan Komunitas, 193-198. 